\title{
ResearchOnline@JCU
}

This is the Submitted Version of a paper published in the journal: Journal of Environmental Management

Arias, Adrian (2015) Understanding and managing compliance in the nature conservation context. Journal of Environmental Management, 135. pp. 134-143.

http://dx.doi.org/10.1016/j.jenvman.2015.02.013 


\section{Understanding and managing compliance in the nature conservation context}

Adrian Arias $^{\mathrm{a}}$

${ }^{a}$ Australian Research Council Centre of Excellence for Coral Reef Studies, James Cook

University, Townsville, QLD 4811, Australia

\section{Correspondence}

Name: Adrian Arias

Email: adrian.arias@my.jcu.edu.au

Postal Address: Australian Research Council Centre of Excellence for Coral Reef Studies, James Cook University, Townsville, QLD 4811, Australia

\section{Note:}

This is a pre-print of: Arias, A. (2015). Understanding and managing compliance in the nature conservation context. Journal of Environmental Management. doi: http://dx.doi.org/10.1016/j.jenvman.2015.02.013 please cite as such.

This version is nearly identical to the published version. If you would like a copy of the published version please contact me: adrian.arias@my.jcu.edu.au 
Pre-print. Please cite as: Understanding and managing compliance in the nature conservation context. Journal of Environmental Management. doi:

http://dx.doi.org/10.1016/j.jenvman.2015.02.013 


\begin{abstract}
:
Nature conservation relies largely on peoples' rule adherence. However, noncompliance in the conservation context is common: it is one of the largest illegal activities in the world, degrading social, environmental and economic goals. Understanding and managing compliance is key for ensuring effective conservation, nevertheless crucial concepts and tools are scattered in a wide array of literature. Here I review and integrate these concepts and tools in an effort to guide compliance management in the conservation context. First, I address the understanding of compliance by breaking it down into five key questions: who?, what?, when?, where? and why?. Special focus is given to 'why?' because the answer to this question explains the reasons for compliance (and/or noncompliance) and provides significantly useful information for compliance management. Second, I succinctly review compliance management strategies, from voluntary compliance to coerced compliance. Finally, I suggest a system, initially proposed for tax compliance, to balance these multiple compliance management strategies. While there is some information about compliance in the conservation literature, the focus is typically on measuring compliance (e.g., methods). This manuscript differs from others by providing theory and tools for understanding compliance, and by addressing compliance management.
\end{abstract}

\title{
Keywords:
}

Enforcement; conservation; illegal resource use; poaching; natural resource management; behaviour

Pre-print. Please cite as: Understanding and managing compliance in the nature conservation context. Journal of Environmental Management. doi: 


\section{Introduction}

Central to nature conservation, from species to ecosystem scales, is the regulation of human activities. There are countless regulations set towards nature conservation; however, noncompliance is often the rule rather than the exception. Illegal wildlife trade; illegal, unreported and unregulated fishing; and illegal timber trade are amongst the largest illicit activities in the world (Haken, 2011). The economic, social and environmental impacts of noncompliance in the conservation context can be broad. Illegal fishing, for example, affects food security, causes the loss of millions of dollars of catch, and creates overexploitation and environmental degradation (MRAG, 2005). And the impacts from noncompliance can be extreme, driving extinctions (Branch et al., 2013; Wilkie et al., 2011), and even the death of poachers and the murder of protected area wardens (Dudley et al., 2013). Compliance, though, receives relatively little focus in the conservation literature when compared to other aspects of nature conservation. However, recent contributions are advancing the knowledge about compliance management in the nature conservation context, reviewing methods (Bergseth et al., 2013; Gavin et al., 2010) and theory (Gibbs et al., 2010; St. John et al., 2013). This review is aimed at conservation practitioners ${ }^{1}$, it expands on recent contributions and integrates key concepts and tools from other disciplines to facilitate compliance management in the conservation context.

Compliance is rule adherence. Rules have targets, which, in the nature conservation context, can be wide-ranging (e.g., water, forests, fish, or rhinos). Depending on its magnitude, noncompliance can render a rule ineffective; meaning that the state of its target would probably be the same as without a rule: defeating the rule's purpose. Thus, effective conservation relies on peoples' compliance. However, what is a "high" level of compliance and how can it be attained? The key concepts and tools that help understand and manage compliance are dispersed in a wide array of literature; for example well-known theories and ideas from sociology and economics. Here, I review and integrate these key concepts and tools to guide the understanding and management of compliance in the conservation context.

Successful compliance management interventions can rely on a firm understanding of the factors causing compliance, which is inherently difficult given the illegal nature of noncompliance. Furthermore, additional factors besides the causes for compliance can be very useful for practitioners. Thus, I explore compliance using the Kiping Method or 5W's (who?, what?, where?, when?, and-perhaps the most vital-why?). Here I look at each of the 5W's, focusing on why, and their relevance for understanding compliance. After reviewing compliance with these key aspects I then suggest a system that can be used to manage compliance (Figure 1). Because of the breadth of compliance in the nature conservation context this is not intended to be an exhaustive review, but rather one that enriches the nature conservation literature, facilitates discussion and, most importantly, action.

\footnotetext{
1 "Practitioners are managers, researchers, and local stakeholders who are responsible for designing, managing, and monitoring conservation and development projects” (Margoluis \& Salafsky, 1998, p. 7)
}

Pre-print. Please cite as: Understanding and managing compliance in the nature conservation context. Journal of Environmental Management. doi: http://dx.doi.org/10.1016/j.jenvman.2015.02.013 


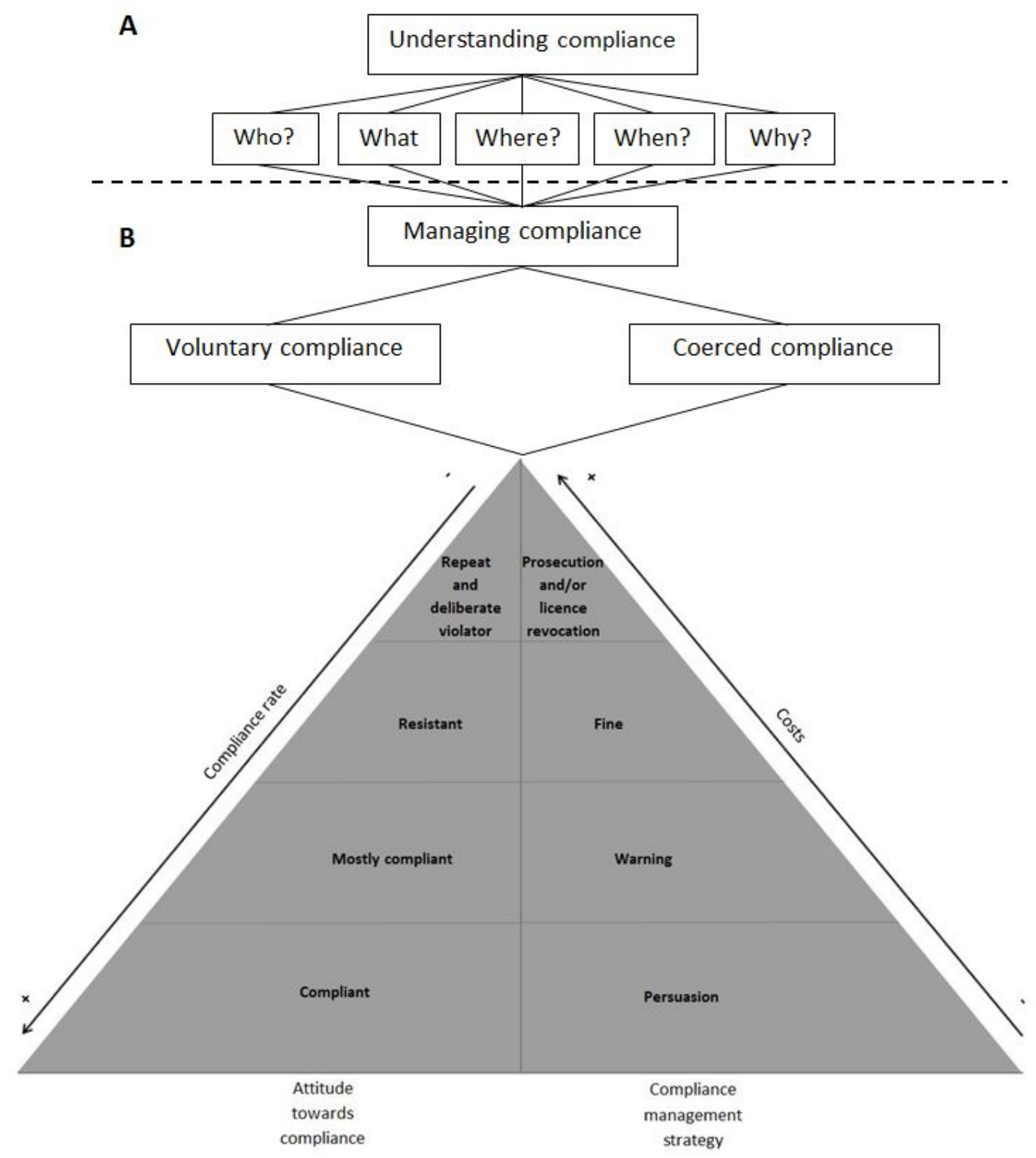

Figure 1. Heuristic of a system for (A) understanding and (B) managing compliance.

\section{Understanding compliance}

\subsection{The 5W's}

Journalists and law enforcement officers typically use the 5W's to gather a complete story, here I draw on the same tool and break down compliance in the following questions, with no particular order: 1) Who complies (or not)?; 2) What is the noncompliance act?; 3)

Pre-print. Please cite as: Understanding and managing compliance in the nature conservation context. Journal of Environmental Management. doi:

http://dx.doi.org/10.1016/j.jenvman.2015.02.013 
Where is noncompliance occurring?; 4) When is noncompliance occurring?; and 5) Why is compliance (or noncompliance) occurring?

\subsubsection{Who complies or not}

Management interventions can be focused when compliers and/or non-compliers are known. The focus of interventions, however, can be variable because the answer to this question can be multilayered. For example: Is it a particular community engaging in illegal activities? Or a particular group of people within the community? Is it several people or just one person? Are they male or female, young or old? Multiple studies have made this distinction to some extent. In the Calamianes Islands, Philippines, Fabinyi (2007) determined that local males between teenage to early twenties were more likely to fish illegally. Likewise, (Cinner, 2010) found that the poor were more likely to use illegal destructive fishing gear in Kenya and Tanzania. Noncompliance can also be driven by people outside local communities (Berkes et al., 2006; Leader-Williams et al., 1990), necessitating special attention when designing interventions such as patrols, investigation and awareness campaigns.

Additional layers can apply to this question in terms of the complicity chain. Going back to the previous illegal fishing example in the Philippines, a practitioner might discover a bigger story when investigating who is an accomplice: who is providing the cyanide that the young illegal fishermen use? And, who buys the illegally caught fish from them? These questions can be very relevant for compliance management. For instance, campaigns condemning the consumption of wildlife products such as shark fins (Dell'Apa et al., 2014) and ivory (Stiles, 2004) are common. Such campaigns appeal to consumers, raising their awareness on facts such as the illegality, cruelty, and/or social or environmental impacts of consuming these products. Also, knowing who markets or deals natural resources illegally might be more effective than focusing on immediate noncompliers in the field. Clayton et al. (1997) explain how it is easier to deter the illegal hunting of a wild pig species in Indonesia by focusing on markets and road checks than by patrolling for illegal hunters in the field. Also, by reducing demand illegal hunting becomes less profitable for hunters. Knowledge of who does not comply can, and in many cases should, typically go beyond identifying individuals or groups (e.g., 'fishermen' or particular community) who immediately break the rules. And understanding of the complicity chain can provide a better idea of the situation, improving the chances of effective compliance management.

Knowing who complies can also be beneficial. Compliers can provide useful information to help understand and manage compliance, and might also positively affect compliance by acting, consciously or not, as enforcers. In Zambia, Jachmann and Billiouw (1997) report the success of an enforcement system using investigations aided by cash rewards for information that led to arrests or confiscations. Using this system, arrests became four times more cost effective than foot patrols (Jachmann \& Billiouw, 1997). Note, however, that noncompliers could also serve as key informants. In the Great Barrier Reef Marine Park, Australia, the management authority has a system in place where people can report illegal activities seen within the Park, such as littering, fishing in closed areas, and taking more than the approved number of tourists to an area. Reports can be filed by telephone or online (GBRMPA, 2014).

Pre-print. Please cite as: Understanding and managing compliance in the nature conservation context. Journal of Environmental Management. doi: 
Such reporting mechanisms provide a means of self-enforcement, urging some to comply. Understanding compliers, their traits and stimuli, proves particularly useful when trying to answer "Why is compliance occurring?", this concept is developed in that section of the paper.

\subsubsection{What is the noncompliance act}

The answer to this question should explain what is being done illegally and in what way (or how). In some cases this can be a simple question to answer. Take for instance tourists walking off-track in a protected area. "Tourists" is a broad description for "who?", and should ideally be unpacked to provide more information (e.g., first time or frequent visitors, age), but the noncompliance act ("what?") is simple to describe (i.e., "walking off-track") and cannot be unpacked. However, sometimes the noncompliance act can be further described. For instance, if fishing is the noncompliance act, a full answer to this question should include the method/gear being used and the organism(s) being extracted.

Knowing the method or methods used for noncompliance can be highly relevant. For example, in case of extractive uses such as hunting and fishing, selectivity is commonly dictated by the method used. While methods such as wire snares or fishing nets can be used with the intention of targeting particular species, their selectivity is low and can result in considerable levels of by-catch (unintentional catch). Becker et al. (2013) evaluated wire snare poaching in Zambia and concluded that this method considerably increases the mortality of elephant, lion and wild dogs, all non-target threatened species. Thus, knowledge of the methods used and the species being affected by noncompliance can help estimate the environmental impact of noncompliance and can inform the design of adequate interventions.

\subsubsection{Where is the noncompliance occurring}

Knowing the location of noncompliance is useful because it informs practitioners where interventions such as monitoring, enforcement and/or communication efforts should be focused. The place where noncompliance occurs can be highly variable, from geographically widespread (e.g., illegal logging (Laurance, 1998)) to very localized (e.g., point pollution in a river). In some instances, however, noncompliance can be known to be occurring while its source location remains unknown. An example of this is the illegal trade of plants, animals and their derivatives. In this case determining the source location of noncompliance would likely involve more complex investigations. Such investigations can include wildlife DNA forensics, a tool that can establish the species, geographical origin and even if it was wildcaught or not (Ogden et al., 2009). This case again highlights the importance of monitoring and influencing markets, and having legal prescriptions that allow sanctioning not only immediate noncompliers in the field but also those involved in illegal trade at various geographical scales.

\subsubsection{When is the noncompliance act occurring}

Similar to knowing where noncompliance is occurring, knowing the time (including frequency) of noncompliance helps optimize interventions, particularly patrols which can be

Pre-print. Please cite as: Understanding and managing compliance in the nature conservation context. Journal of Environmental Management. doi: http://dx.doi.org/10.1016/j.jenvman.2015.02.013 
better allocated. Noncompliance can be opportunistic (Eliason \& Dodder, 1999; MilnerGulland \& Leader-Williams, 1992), but can also respond to environmental and biological variables, and/or even management actions. When analysing illegal fishing in a marine protected area Arias et al. (2014) found that illegal fishing was more likely to occur during the new moon phases of the third quarter of the year. The combination of time of the year and lunar phase was likely to maximize illegal catch because of oceanographic and ecological reasons. By learning about what the noncompliance act is practitioners could, in some cases, elicit when these acts are occurring because of factors such as seasonality (e.g., vacations, migrations, aggregations) or deil patterns (e.g., nocturnal vs diurnal activity).

Noncompliers are likely to adopt strategies to evade detection, such as acting at night, or when patrols are limited or inexistent. This might have been the case with the previous example-the new moon involves darker nights and this can further reduce the probability of detecting illegal fishing (Arias et al., 2014). Because noncompliers can learn about the timing (and location) of patrols and act outside these times, integrating a degree of randomness in patrols, and systematic and periodic analyses of patrol records can be useful to break such cycles.

\subsubsection{Why is compliance and/or noncompliance occurring?}

The previous points focused on describing compliance and/or noncompliance, whereas this section focuses on explaining it. Prior W's clearly define the behaviour (Ajzen \& Fishbein, 2005) — they define WHO is doing WHAT, WHEN and WHERE. And finally, why? explains the behaviour.

Practitioners and scholars should identify and address the specific factors that are salient for maintaining or improving (hereafter: influencing) compliance (Ham, 2013; St. John et al., 2010). Practitioners will typically benefit more when understanding what influences compliance rather than what causes noncompliance, because compliance is the desired behaviour. However, understanding why people break rules could also help contextualize the problem and design solutions. Compliance is a dichotomous variable (i.e., either there is compliance or not), yet, it is important to mention that knowing why someone follows a rule is not necessarily the opposite of knowing why someone breaks it. For instance, if a manager knows that people fish illegally in a closed area because they believe that there are more fish there, it would not be valid to assume that those who comply do so because they think that there are less fish in the closed area (Arias \& Sutton, 2013). Management interventions can have better chances of being successful when the factors influencing compliance are understood.

Perhaps the main reason for why useful information about compliance is distributed so widely in the literature (e.g., sociology, criminology, anthropology, psychology, economics) is because compliance is highly relevant for many fields. Essentially, compliance is critical for a functional society. Consequently, there is a long history of trying to understand why people comply or not. The understanding of compliance advanced during the Age of Enlightenment. This change came with the expansion of knowledge through the scientific

Pre-print. Please cite as: Understanding and managing compliance in the nature conservation context. Journal of Environmental Management. doi: 
method; and with thinkers, such as Descartes, Locke, and Rousseau, accrediting reason and free will to people's behaviour (Barkan, 2011). As a response to the unjust and ineffective European justice system during the 1700s, Cesare Beccaria presented, in 1775, a theory which sparked the field of criminology. Beccaria's theory is that people take rational choices to maximize pleasure and reduce pain, and by doing so they can break rules (Cullen \& Agnew, 2006). He proposed that sanctions were necessary, but to be effective these must be clear, well known, proportionate to the offense, quick, and certain. This theory stood alone for nearly a century, influencing reforms in Europe and USA, but was challenged in 1876 by Cesare Lombroso (Cullen \& Agnew, 2006). By studying individuals Lombroso, a physician, believed that criminals could be differentiated by observable physical traits, a theory that was followed by others and later led to eugenics (Winfree \& Abadinsky, 2009). Lombroso's theory was rejected, but he is credited for pioneering the use of the scientific method to explore crime. Some of Beccaria's ideas also persist, such as the responsibility that each person holds for their actions and how the certainty of sanctions reflects on crime (Cullen \& Agnew, 2006). More recent theories suggest that compliance is explained by a combination of factors such as economics and social norms (Cullen \& Agnew, 2006; Tyler, 1990).

The factors influencing compliance have been widely studied in psychology and sociology. Fishbein and Ajzen (2010) offer a widely used model for predicting, explaining and changing behaviour - the Reasoned Action Model (also known as Theory of Planned Behaviour). The model suggests that three key beliefs drive a person's intention to behave (in this case comply) or not. The three beliefs are behavioural beliefs, normative beliefs, and control beliefs. Behavioural beliefs relate to the positive or negative consequences associated to the behaviour (e.g., "If I comply I will not get punished by the law"). Normative beliefs are the social pressures controlling a person's behaviour (e.g., "Noncompliance is unacceptable in my social circles"). Control beliefs are factors which ease or hinder behaviour (e.g., "I don't have the skill and/or resources to be noncompliant"). So if a person believes that it is easy to comply, that complying will have a positive outcome, and that compliance will be well received by others, there will be a strong intention to comply. There are other theories that can help explain compliance (see for example: Maslow, 1943; Rogers, 1975). However, here I focus on the Reasoned Action Model because it is simple, effective (Beck \& Ajzen, 1991; Kaiser et al., 2005), and has become one of the most popular and influential in behavioural studies (Ajzen, 2012).

Behavioural beliefs are people's evaluation of the benefits vs. costs of a specific behaviour. For instance, if a hunter concludes that the consequences of complying with hunting regulations are mostly positive or beneficial (e.g., bigger and healthier game populations, licence fees used for conservation/management, etc.) the hunter's attitude towards that behaviour will be positive, and vice versa. Several authors and practitioners focus on the behavioural component of compliance, particularly coercion (Becker, 1974; Hauck \& Kroese, 2006; Kalron, 2013; Peluso, 1993; Sutinen \& Andersen, 1985). Coercion acts as a negative incentive deterring noncompliance, making actors evaluate the potential benefits and costs of noncompliance and compliance. And positive incentives to strengthen compliance by influencing behavioural beliefs can also be used. Behavioural beliefs in the form of positive and negative incentives are discussed further in following sections.

Pre-print. Please cite as: Understanding and managing compliance in the nature conservation context. Journal of Environmental Management. doi: http://dx.doi.org/10.1016/j.jenvman.2015.02.013 
The normative component is particularly important for determining compliance (Tyler, 1990), and it deserves special attention considering that people typically behave in accordance to norms. Cialdini et al. (1991) differentiate three types of norms: personal, descriptive, and injunctive. Personal norms are the moral obligations for engaging or not in a behaviour, with internal sanctions and rewards for doing so (Schwartz, 1973). Descriptive and injunctive norms are social norms that rely on sensed external cues. Descriptive norms are what most others do, whereas injunctive norms are what most others approve or disapprove. So descriptive norms inform behaviours while injunctive norms prescribe and proscribe them (Cialdini et al., 1990).

Personal norms are not part of the Reasoned Action Model but some authors have integrated them into the Model (Harland et al., 1999), and into other, more complex, models (Klöckner, 2013). The Reasoned Action Model is a general model of human behaviour, and Fishbein and Ajzen (2010) suggest that, with some exceptions, personal norms do not add explanatory power to their Model. However, such exceptions where personal norms do help explain behaviour are proenvironmental and prosocial behaviour (Harland et al., 1999, 2007; Schwartz, 1977) — hence personal norms are certainly relevant for compliance. The feeling of being morally obliged to comply or regretting noncompliance are examples of how personal norms can influence compliance and how these norms can be measured in social surveys (Harland et al., 2007). Also, research shows that long lasting behavioural change can be achieved through personal norms (Matthies et al., 2006); once personal norms are activated people are likely to engage in positive behaviours because 'it is the right thing to do'. While not all compliance with environmental rules is driven by morality and altruism some clearly is, therefore practitioners should consider personal norms when trying to understand compliance. Social norms on the other hand are also highly relevant for compliance because people typically behave according to the behaviour of others (Schultz et al., 2007).

Social norms act as rules guiding behaviour. For instance, there are fishing communities in Indonesia where people do not fish on Fridays because of their religious beliefs (Cinner et al., 2012a), this is a social norm. And compliance with these rules can be enforced, for example, through social ostracism (Colding \& Folke, 2001; Sumner, 1906). Social norms, however, are not necessarily weaker or less effective than their formal counterparts. In fact, long-standing social norms regulating natural resource use can be weakened by the superimposition of formal laws, bringing negative social and environmental impacts. Jones et al. (2008) describe multiple social norms regulating terrestrial natural resource use in Madagascar, and mention that these social norms can be preferable to formal laws that are poorly enforced by the state. In the marine environment Gelcich et al. (2006) argue that the effectiveness of a system to manage kelp and mollusc extraction in Chile faded when it transitioned from a traditional access right system to a government led co-management system; compliance dwindled and not only was ecological resilience degraded, but social bonds weakened. Practitioners should aim to understand extant norms and institutions; fostering those that are influencing compliance.

The effect of social norms on pro-environmental behaviour and compliance has been well studied. Cialdini et al. (1990) assessed the impact that descriptive and injunctive norms have on littering in public spaces. Their results show that the presence of litter encourages

Pre-print. Please cite as: Understanding and managing compliance in the nature conservation context. Journal of Environmental Management. doi: 
further littering. This occurs because the presence of litter generates a descriptive norm of what most other people do, so a highly littered place is equated to 'littering is normal'. To assess the effect of the injunctive norm, researchers placed handbills on car windshields, handbills had messages with varying degrees of proximity to the injunctive norm against littering (i.e., do not litter, recycle, turn out lights, vote, celebrate arts month). By surreptitiously observing people's behaviour when they reached their cars, researchers noticed that littering of the handbills decreased as the message on the handbill got closer or was identical to the injunctive norm against littering. In other words, people who received handbills with the injunctive message against littering were the least likely to litter the handbill, whilst those who received the handbill with the message about celebrating arts months were most likely to litter the handbill. This result underlines the importance of delivering specific messages aimed at clearly defined behaviours. General messages (e.g., the typical "Save the environment") are ineffective. Furthermore, poorly designed management interventions aimed at influencing norms can even be counterproductive. For example, signage at a beach with a descriptive statement that "Tons of seashells are stolen every year...” communicates to visitors that 'everyone does it', and can actually increase seashell theft (Cialdini, 2003). These results demonstrate the relevance of understanding what drives compliance for creating influential management interventions.

Lastly, control beliefs-people's perceptions of what can ease or hinder a particular behaviour-can also play a key role in influencing compliance. Examples of control beliefs are knowledge, skills, time, money, weather and equipment. While some control beliefs (e.g., weather), cannot be managed by the governing institution, other control beliefs can be identified and addressed by the governing institution. Knowledge, for instance, is typically used to foster desirable behaviours. In a meta-analysis of recycling behaviour Hornik et al. (1995) found that consumer knowledge about recycling was the strongest predictor of recycling. Nevertheless another control belief, such as the lack of a recycling program, can act as a strong barrier against recycling, even for a person with overall strong and positive beliefs about recycling. Therefore a governing institution that wants to foster a particular behaviour can provide knowledge on why and how to do it, but should, whenever possible, also offer services and/or facilities to ease behaviour performance (e.g., making recycling convenient). A managing institution could apply one or multiple interventions to either facilitate or obstruct peoples' control over performing a particular behaviour. And such interventions can have varying degrees of complexity and success. For instance, a managing institution can hand out brochures or install signs informing about the illegality of using a particular gear, such strategy removes the knowledge barrier (i.e., people not knowing about the regulation). Following the same example, another intervention could be aimed at banning the possession and importation of that particular gear at a national level (e.g., spearguns in Seychelles), this intervention makes it difficult for people to have access to that gear. However, in some cases, illegal gear can be cheap and/or simple to build (e.g., wire snares). Adequate interventions are therefore context specific, just as the relative importance of control beliefs, normative beliefs and behavioural beliefs.

To answer "why?" social surveys are required, although modelling can be used to understand the implications of different motivations for compliance or noncompliance (Table 1). The popularity of the Reasoned Action Model makes it an easily accessible tool, and by

Pre-print. Please cite as: Understanding and managing compliance in the nature conservation context. Journal of Environmental Management. doi: http://dx.doi.org/10.1016/j.jenvman.2015.02.013 
including personal norms it can be effective for understanding compliance. There are guides for the application of the Model, and the subsequent crafting interventions (Fishbein \& Manfredo, 1992; Ham, 2013), including freely available material (Ajzen, 2013; Ham et al., 2009; Ham et al., 2008). The need for social science to understand and manage compliance stresses the fact that conservation is mainly about managing people-not plants, animals or landscapes (Balmford \& Cowling, 2006; Schultz, 2011).

\section{- Additional considerations: Magnitude and units of compliance}

In the introduction I mentioned that low compliance can render a rule ineffective, so high levels of compliance are desired. However, the magnitude of compliance must be defined. It would be overly simplistic to think that the magnitude of compliance is based on the number of people complying or not. For example, consider a forested protected area that has two local people logging illegally. The same two loggers can pose very different scenarios depending on whether they use axes or chainsaws, and/or if they log trees once a year or every day of the year. In this case the number of people, time and/or frequency, and gear are fundamental factors when considering the magnitude of compliance. 'Who?', 'what?' and 'when?' can provide a robust estimate for the magnitude of compliance. By answering 'who?' one can qualitatively or quantitatively establish the amount of noncompliers; 'what?' describes the action and the method used to affect the resource; and 'when' describes the time and/or frequency of noncompliance. Whenever possible, the magnitude of compliance should combine these three factors. However, a) there are other means of estimating the magnitude of compliance; and b) sometimes a compliance manager only needs to confirm the presence or absence of compliance (e.g., to determine someone as guilty or innocent).

Rules are directed at targets (e.g., water, forests, and fish); therefore, the magnitude of compliance can be estimated indirectly through measurable traits on those targets (e.g., water quality, forest coverage, fish biomass). The magnitude of compliance can also be estimated directly though methods such as social surveys, interviewing local people and resource users. This means that the presence or absence of compliance can be established in several ways, and that the magnitude of compliance can have a multiple units of measurement (Bergseth et al., 2013). Importantly, defining magnitudes of compliance allows the establishment of baselines that can then be used to monitor and evaluate management interventions.

A good example to illustrate the importance of answering 'who?', 'what?' and 'when?' when establishing the magnitude of compliance is fish spawning aggregations. For example, several coral reef fish, such as the Nassau grouper (Epinephelus striatus), form large reproductive aggregations. These aggregations are predictable in both space and time, and the species grows slowly and is late to mature; hence, the Nassau grouper is highly vulnerable to overfishing. Noncompliance with conservation measures set for Nassau grouper have caused alarming declines in their populations (Sadovy de Mitcheson et al., 2008). The species is typically spearfished by divers who know the time and place of these aggregations. Therefore common methods for managing the extraction of this species are temporal and spatial closures, and regulating or prohibiting the use of spearguns (Sala et al., 2001). Ultimately, the magnitude of fishing, either legal or not, that the Nassau grouper is lower than that of fish

Pre-print. Please cite as: Understanding and managing compliance in the nature conservation context. Journal of Environmental Management. doi: 
with opposite biological characteristics (i.e., non-aggregating, and fast growing and maturing).

\subsection{Methods to study compliance}

A particular obstacle exists when studying compliance with conservation regulations. Compliance is expected-morally, socially and/or legally—, making noncompliance a clandestine behaviour, and compliance a socially desired behaviour. Hence, a high bias is expected if inadequate methods are used to study compliance. For example, when social surveys are used to gauge compliance, noncompliers could refuse to participate and/or provide deceitful responses. Fortunately several methods exist to circumvent these obstacles (Table 1). Depending on the question that needs answering (e.g., who, what, when, where, and why) practitioners can choose from these different methods. Budget, labour demand and technological requirements also influence method selection (Gavin et al., 2010). Social surveys are typically the simplest method and can provide large amounts of information, but have the potential for response or non-response bias. However, they can be used in conjunction with additional elements that reduce bias (Jaccard \& Blanton, 2005). For instance, specialized questioning techniques such as the random response technique, ensuring confidentiality or anonymity, underlining the importance of accurate data, and using neutral interviewers (e.g., students instead of government staff) can all reduce bias in social surveys.

Pre-print. Please cite as: Understanding and managing compliance in the nature conservation context. Journal of Environmental Management. doi: http://dx.doi.org/10.1016/j.jenvman.2015.02.013 
Table 1. Methods for studying compliance. Adapted from Bergseth et al. (2013) and Gavin et al. (2010).

\begin{tabular}{|c|c|c|c|c|c|c|c|c|}
\hline \multirow[b]{2}{*}{ Methods } & \multirow[b]{2}{*}{ Examples } & \multirow[b]{2}{*}{ Units } & \multicolumn{5}{|c|}{5 W's } & \multirow[b]{2}{*}{ References } \\
\hline & & & $\begin{array}{l}\text { Wha } \\
\text { t }\end{array}$ & $\begin{array}{l}\text { Wh } \\
\mathbf{y}\end{array}$ & $\begin{array}{l}\text { Whe } \\
\text { n }\end{array}$ & $\begin{array}{l}\text { Wher } \\
\text { e }\end{array}$ & $\begin{array}{l}\text { Wh } \\
\text { o }\end{array}$ & \\
\hline $\begin{array}{l}\text { Social } \\
\text { surveys }\end{array}$ & $\begin{array}{l}\text { Expert elicitation, random } \\
\text { response technique, perceived } \\
\text { compliance, item count, self- } \\
\text { reporting }\end{array}$ & $\begin{array}{l}\text { proportions, likert } \\
\text { scales, geographic, } \\
\text { effort }\end{array}$ & $\checkmark$ & $\checkmark$ & $\checkmark$ & $\checkmark$ & $\checkmark$ & $\begin{array}{l}\text { (Arias \& Sutton, 2013; Cinner et } \\
\text { al., 2012b; Knapp et al., 2010; } \\
\text { Nuno et al., 2013) }\end{array}$ \\
\hline Modelling & $\begin{array}{l}\text { predictions of illegal resource } \\
\text { use and resource dynamics, } \\
\text { spatiotemporal patterns }\end{array}$ & $\begin{array}{l}\text { absolute measures } \\
\text { (e.g., effort, } \\
\text { biomass) and } \\
\text { response ratios }\end{array}$ & $\checkmark$ & $\checkmark$ & $\checkmark$ & $\checkmark$ & $\checkmark$ & $\begin{array}{l}\text { (Ainsworth et al., 2012; } \\
\text { Jachmann \& Billiouw, 1997; } \\
\text { Keane et al., 2012; Little et al., } \\
\text { 2005) }\end{array}$ \\
\hline $\begin{array}{l}\text { Law } \\
\text { enforcement } \\
\text { records }\end{array}$ & $\begin{array}{l}\text { Foot or vehicle based patrol } \\
\text { records, legal proceedings }\end{array}$ & $\begin{array}{l}\text { number of } \\
\text { detections, } \\
\text { arrests/citations, } \\
\text { prosecutions, } \\
\text { absolute measures } \\
\text { (e.g. time and } \\
\text { area) }\end{array}$ & $\checkmark$ & $x$ & $\checkmark$ & $\checkmark$ & $\checkmark$ & $\begin{array}{l}\text { (Akella \& Cannon, 2004; Arias } \\
\text { et al., 2014; Hilborn et al., 2006; } \\
\text { Holmern et al., 2007) }\end{array}$ \\
\hline $\begin{array}{l}\text { Indirect } \\
\text { observation }\end{array}$ & $\begin{array}{l}\text { Discarded or set gear (e.g., } \\
\text { traps, bullet casings), } \\
\text { carcasses, animal behaviour, } \\
\text { markets }\end{array}$ & $\begin{array}{l}\text { absolute measures, } \\
\text { flight initiation } \\
\text { distance }\end{array}$ & $\checkmark$ & $x$ & $\checkmark$ & $\checkmark$ & $x$ & $\begin{array}{l}\text { (Clayton et al., 1997; } \\
\text { Januchowski-Hartley et al., } \\
\text { 2012) }\end{array}$ \\
\hline $\begin{array}{l}\text { Remote } \\
\text { sensing }\end{array}$ & $\begin{array}{l}\text { Forest cover, satellite tracking, } \\
\text { drones }\end{array}$ & absolute measures & $\checkmark$ & $x$ & $\checkmark$ & $\checkmark$ & $\checkmark$ & $\begin{array}{l}\text { (Brooke et al., 2010; Kuemmerle } \\
\text { et al., 2009; Lein, 2009) }\end{array}$ \\
\hline $\begin{array}{l}\text { Forensic } \\
\text { studies }\end{array}$ & Genetic and chemical analysis & absolute measures & $\checkmark$ & $x$ & $\checkmark$ & $\checkmark$ & $\checkmark$ & $\begin{array}{l}\text { (Mak et al., 2005; Ogden, 2008; } \\
\text { Ogden et al., 2009) }\end{array}$ \\
\hline
\end{tabular}

Pre-print. Please cite as: Understanding and managing compliance in the nature conservation context. Journal of

Environmental Management. doi: http://dx.doi.org/10.1016/j.jenvman.2015.02.013 


\section{Managing compliance}

Compliance is never complete (Hart, 1994; Tyler, 1990): not all people comply, and not all of them comply for the same reasons. Hence there is a need for comprehensive compliance management schemes, even when compliance is prevalent. Compliance can be voluntary or coerced. Each strategy, however, should correspond to a particular type of individual, varying from the always compliant to the repeat and blatant offenders (Fig. 1). With the caveat that perverse outcomes can arise when a strategy is misapplied. For example, a hiker who unintentionally enters a closed area in a National Park by being unaware about the closure and/or unskilled at navigation would likely benefit from persuasive communication (e.g., signs, brochures or short talks from rangers). Nevertheless, a hunter who repeatedly and knowingly enters that same area would be more likely to comply if subjected with a punitive strategy (e.g., fine, gear confiscation, imprisonment). If these two strategies were applied inversely, the result would be business as usual for the illegal hunter, and an antagonized hiker. This exemplifies how compliance managers can benefit from appropriate information (understanding) to design and apply compliance management strategies.

\subsection{Voluntary compliance}

Practitioners should aim for voluntary compliance. A high level of voluntary compliance is preferred because it: 1 ) reflects that most natural resource users are assertive about the benefits of compliance, 2) provides a buffer when costly enforcement is paused (e.g., patrol unit breaks down) and 3) confirms effective governance and management. Here I define voluntary compliance as that which is performed purposefully as an act of approval with the rules and institutions, either when punishment is applicable or not. Levi (1989) uses the term 'quasi-voluntary compliance' when punishment is applicable in case of noncompliance, or as stated by Hart (1994, p. 198) "voluntary cooperation in a coercive system”. The main tools used to promote voluntary compliance are legitimacy, incentives, alternatives, and persuasive communication.

\subsubsection{Legitimacy}

Voluntary compliance requires constant input from the regulating institution. Positive opinions about the regulating institution will generate a sense of legitimacy and in turn increase voluntary compliance (Tyler, 1990). Empirical studies in the conservation context support the value of legitimacy to influence compliance. McClanahan et al. (2006) point to the perception of legitimate regulations as the likely explanation for high compliance in the absence of regular enforcement in traditionally managed areas in Indonesia and Papua New Guinea. Hønneland (2000) reported similar conclusions when studying fishermen in the Barents Sea; he noted how some enforcement was necessary to ensure compliance, but it was not as significant as the perception of legitimate regulations, procedures and authorities.

A governing institution expects positive results on natural resources from rule compliance, for instance clean water and increased biomass. In exchange for their compliance, natural resource users will typically expect not only positive results on the natural resources, but also evidence of efforts on behalf of the governing institution to ensure

Pre-print. Please cite as: Understanding and managing compliance in the nature conservation context. Journal of Environmental Management. doi: http://dx.doi.org/10.1016/j.jenvman.2015.02.013 
those positive results. The perceived effectiveness and justness of these efforts will dictate the degree of legitimacy granted to the institution (Levi et al., 2009). Thus, regulating institutions can reduce or increase compliance through their actions. For example some noncompliance can be explained as a response to what natural resource users believe is illegitimate (Stern, 2008). It is therefore the task of the regulating institution to ensure legitimacy (Knopf \& Dustin, 1992). This feedback loop calls for the inclusion of social, economic and political contexts in early stages of nature conservation plans (Ban et al., 2013; Pressey \& Bottrill, 2009).

\subsubsection{Incentives}

Incentives are economic in nature and therefore typically affect behavioural beliefs. Incentives can take multiple forms, for instance awards and public recognition, information and training, and monetary/financial incentives (Stonehouse, 1996). Incentives can be granted to regulators (e.g., wardens) as well as natural resource users. Jachmann (2008) reports how patrol staff from different protected sites in Ghana improved work performance when they started competing against each other, and when information about their performance was made public. In this case the incentive for patrol staff to do a better job was recognition. This example shows how incentives can improve interventions; however, incentives can sometimes backfire (Fehr \& Falk, 2002).

As reviewed earlier, norms can have a strong effect on compliance: people can comply predominantly because they believe it is morally the right thing to do and/or because it is socially accepted. Nevertheless, the introduction of external incentives can change the motivation to comply, giving dominance to behavioural (economic) beliefs over normative beliefs. Hence, the motivation to comply can shift: from expecting no reward in exchange for compliance other than the positive moral stance of being compliant, to the expectations of a contract involving an economic transaction. This shift has been well documented in psychology and economics (Deci et al., 1999; Frey \& Jegen, 2001). An example of this effect (called "hidden costs of reward" or more recently "crowding-out effect") in the conservation context is portrayed by tradable emission rights, where a company has a "licence to pollute" and therefore the moral motivations to lessen pollution are greatly reduced because pollution is legitimized (Frey, 1999). In a small artisanal fishing community in Costa Rica fishermen receive money from a nongovernment organization to buy fuel for patrolling a fishing area at night; fishermen patrol voluntarily using their boats and they rotate shifts (A. Arias pers. obs.). Fishermen benefit from patrols because they deter the use of illegal nets within the fishing area, and the financial costs of buying the fuel themselves would be high. However, one must question whether fishers' motivation to patrol the area would remain if (or mostly likely 'when') this external incentive disappears. In fact, while some fishers mention increased catch as a result of patrolling the area, several argue that they should receive a salary for patrolling (A. Arias pers. obs.). Despite good intentions from the organization providing the fuel, fishers' motivations seem to have been negatively affected. Practitioners should therefore be cautious when applying incentives as these can have unaccounted consequences that can be then difficult or impossible to reverse.

Pre-print. Please cite as: Understanding and managing compliance in the nature conservation context. Journal of Environmental Management. doi: http://dx.doi.org/10.1016/j.jenvman.2015.02.013 


\subsubsection{Alternatives}

Undesired practices can be replaced by more desirable alternatives. Because this approach aims to draw people's attention from practices that are environmentally undesired, Franz Tattenbach suggested the term “conservation by distraction” (Ferraro \& Simpson, 2002). These distractions are typically introduced through alternative livelihoods and are central in integrated conservation and development projects. Introducing alternative goods, such as western synthetic medicine to replace traditional medicine, can also be considered within this approach (Milner-Gulland \& Rowcliffe, 2007). There are successful examples of conservation by distraction, for example some cases of ecotourism (Ferraro \& Hanauer, 2014; Wunder, 2000). However, as with positive incentives, alternatives can bring damaging and unintended consequences if they are not well designed and managed. Sievanen et al. (2005) describe how seaweed farming projects were introduced in the Philippines, particularly to reduce fishing pressure. Seaweed farming did bring benefits such as reducing some types of fishing, some people earning more money, farms acting as fish aggregating devices and people prohibiting netting near the farms to prevent damaging them. But seaweed farming also brought perverse outcomes such as attracting numerous outsiders to the small villages were farming was taking place, people using mangrove wood to build their farms, pollution from discarded materials, and boom and bust cycles due to market prices and disease infestations. Mixed results from the introduction of alternatives have been reported elsewhere (Baker et al., 2013), raising an important caveat when practitioners consider using alternatives to reduce noncompliance and/or undesired practices.

\subsubsection{Persuasive communication}

Through communication a person can be persuaded to comply voluntarily. Studies show that when persuasive communication successfully activates in a person's mind it can reinforce, change or create new beliefs (Ham, 2013). Hence, persuasive communication can significantly enhance the likelihood of voluntary compliance. Large scale communication efforts such as education and outreach campaigns can be expensive (Alder, 1996; McKenzieMohr, 2000), particularly in remote areas with limited media resources such as radio and television, but compared to enforcement, they can offer broader benefits such as environmental knowledge ${ }^{2}$ and pro-environmental behaviour (Leisher et al., 2012).

As mentioned previously, understanding what drives compliance can greatly help design communication strategies. And by applying key knowledge on psychology and sociology, such as the Reasoned Action Model, practitioners can strengthen their communication efforts. By using persuasive communication, informed through the Reasoned Action Model, Brown et al. (2010) describe how visitors were influenced to pick up other people's litter in a National Park in Tasmania. Practitioners created two signs with thought-provoking titles ("What will you do when you see it" and "If not you, who?") followed by short sentences related to the titles and the target behaviour (litter pick up in the Park). The signs increased litter pickup by $15-20 \%$. Littering was considered to be the outmost visitor problem in the National Park, so by increasing visitor litter pick up the Park was more likely to influence a

\footnotetext{
${ }^{2}$ Note, however, that increased knowledge does not necessarily translate to a change in behaviour (Schultz, 2002)

Pre-print. Please cite as: Understanding and managing compliance in the nature conservation context. Journal of Environmental Management. doi:

http://dx.doi.org/10.1016/j.jenvman.2015.02.013
} 
positive behaviour on visitors, improve its appearance by having less litter, and reduce management costs by having visitors, not staff, picking up litter (Brown et al., 2010).

Persuasive communication, however, is a tool that does not influence all the types of individuals. Persuasive communication is particularly effective for managing uninformed and inexperienced actions that result in noncompliance. Persuasive communication is also likely to make people reason and create significant and lasting changes in their behaviour (Ajzen, 1992). But persuasive communication is ineffective for dealing with people who have ingrained beliefs resulting in deliberate and persistent noncompliance-these cases usually require enforcement measures (Roggenbuck, 1992; Tyler, 1990).

\subsection{Coerced compliance}

Coercion can be an effective strategy to deter noncompliance and to ensure natural resource users that noncompliers will be punished. Levi et al. (2012) suggest that effective enforcement can strengthen an institution's legitimacy by indicating competence, an antecedent for trustworthiness. Although coercion aims to force compliance, it can also be linked to legitimacy and therefore to voluntary compliance.

\subsubsection{Enforcement}

Enforcement is a tool to reach compliance. Effective enforcement is a chain with four links. First, the probability of detecting offenses; second, the probability of arrest or citation given detection; third, the probability of prosecution given arrest or citation; and fourth, the probability of conviction given prosecution (Akella \& Cannon, 2004; Sutinen, 1987). Enforcement acts as a negative incentive, causing resource users to weight economic decisions (behavioural beliefs) related to their compliance: the benefits of acting illegally vs. the chances and repercussions of getting caught doing so. Effective enforcement can be complex to manage because of the diverse steps involved, requiring strong institutions to ensure deterrence. In developing countries, many which are biodiversity rich, enforcement is commonly weak (Akella \& Cannon, 2004). But even in wealthy countries enforcement is only capable of detecting a small fraction of infringements (Stern, 2008; Sutinen \& Kuperan, 1999). Additionally, enforcement is considerably expensive in both land and sea. In the Great Barrier Reef Marine Park, Australia, enforcement accounts for approximately 30\% of the management costs (McCook et al., 2010). In India, approximately 60\% of the forest department's budget is estimated to be spent on enforcement activities (Robinson et al., 2010). Enforcement should therefore be used efficiently.

Enforcement should be targeted. And targets exist in space and time. For instance, (Arias et al., 2014) determined the spatial and temporal distribution of illegal fishing in a marine protected area, thus helping to inform patrol effort. Enforcement can also become more efficient through investigations. And as mentioned previously, markets can be good places to gather information about acts of noncompliance. In Costa Rica, a manager reported seeing unusually large fish being sold in a market adjacent to a no-take marine protected area at the time when patrol boats were inoperative (M. Chavarría, pers. comm.). Larger fish are expected within no-take marine protected areas; therefore this observation suggested that illegal fishing was taking place. Investigative work is key for targeting offenders [including corrupt officers (Sundström, 2012)] who typically employ techniques to avoid detection. A

Pre-print. Please cite as: Understanding and managing compliance in the nature conservation context. Journal of Environmental Management. doi:

http://dx.doi.org/10.1016/j.jenvman.2015.02.013 
major reform of South Africa's fisheries compliance allowed solving several high profile cases through investigative work and a specialized environmental court (Hauck \& Kroese, 2006). However, Hauck and Kroese (2006) mention that this reform was focused on enforcement and, despite several benefits, there was a need to shift towards a system that would prioritize voluntary compliance. These cases show how some enforcement is typically necessary and that there are ways of improving it; nevertheless, it must also be combined with other compliance management strategies that foster voluntary compliance.

\subsection{Balancing compliance management strategies}

Tax compliance has made considerable progress in managing compliance and can provide lessons for nature conservation. The Australian Taxation Office, applies a model which strives for voluntary compliance and relies on graduated sanctions (Braithwaite \& Braithwaite, 2001). The model assumes that most people are compliant and applies a 'softer' approach, such as persuasion, then gradually increasing sanctions according to the number and severity of violations. Costs are reduced by directing expensive and resource intensive measures to the smaller proportion of noncompliers (Figure 1). Furthermore, through graduated sanctions, the model is more likely to be deemed as legitimate and procedurally just - two normative beliefs that influence voluntary compliance (Levi et al., 2012; Ostrom, 1990; Tyler, 2003). Applying strong sanctions at once can not only be seen as illegitimate, but can have adverse effects such as increasing the chances for bribery and violence, foster the investment in methods to avoid detection, stronger defences in court, and having a stronger effect on the poor as compared to the wealthy (Keane et al., 2008; Robinson et al., 2010). Similar to how positive incentives can legitimize environmental harms (e.g., tradable emission rights), negative incentives such as fines and punishment can legitimise noncompliance (Gneezy \& Rustichini, 2000), highlighting the importance of making the sanction proportional to the infraction to reduce this effect. Whilst some regulatory agencies possess the legal framework allowing graduated sanctions, others might have to undergo policy and legislation changes to allow it. Political will is crucial for effective compliance management (Gibson, 1999).

Practitioners should focus on building and strengthening a wide base of voluntary compliance. People commonly follow the behaviour of others (Cialdini \& Goldstein, 2004; Schultz et al., 2007)—social norms. So once these normative beliefs are activated, compliance becomes the norm, at least in the immediate time frame. However, the opposite also applies. Compliers are unlikely to tolerate the burden of noncompliance (i.e., free riding and/or degraded goods), so compliance will progressively deteriorate as compliers defect (Levi, 1989). These thresholds, nevertheless, can be difficult to locate because they depend on dynamic factor such as norms, punishment, and rewards (Fehr \& Fischbacher, 2003; Ostrom, 2000). In practice, simply knowing that these thresholds exist is useful, acting as encouragement for staying away from them by striving for a strong base of voluntary compliance.

Despite the preference for a strong base of voluntary compliance, in some cases noncompliance prevails (Arias et al., 2014; Laurance, 1998), and prompt action is needed to stop further degradation of both the environment and compliance. Cases with high noncompliance can resemble the pyramid in Fig 1B, but with an inverted factor order. However, the relationship between attitudes toward compliance and compliance management

Pre-print. Please cite as: Understanding and managing compliance in the nature conservation context. Journal of Environmental Management. doi: http://dx.doi.org/10.1016/j.jenvman.2015.02.013 
strategies remains the same. Enforcement can offer fast results by disrupting the economic incentives_-behavioural beliefs_-driving noncompliance, and allowing time for sloweracting strategies to come into effect.

\section{Conclusion}

Nature conservation requires compliance. Here I outlined some of the key concepts and tools for understanding and managing compliance. By gathering as much information as possible about the 5W's practitioners can attain valuable information to understand compliance. A complete understanding of compliance also involves knowing the magnitude of compliance. This enhanced understanding provides better chances for managing compliance. The ultimate goal of compliance management is building and maintaining a wide base of voluntary compliance. Voluntary compliance requires constant work from governing institutions, which can be either formal or informal, and relies on key factors such as legitimacy, incentives, alternatives, communication and optimized enforcement. Further interdisciplinary integration and linkages between scholars and practitioners would prove highly beneficial for compliance management in the nature conservation context.

Conservation is ultimately about avoiding loss and averting threats—goals that can only be attained by influencing behaviour.

Pre-print. Please cite as: Understanding and managing compliance in the nature conservation context. Journal of Environmental Management. doi: 


\section{Acknowledgements}

Special thanks to Sam Ham for introducing me to and guiding me through the captivating tangle of human behaviour. I thank Josh Cinner, Brock Bergseth, Amy Diedrich, Jorge Álvarez-Romero and Bob Pressey for their help. I also express gratitude to the Australian Research Council, and the Australian people for support through AusAID.

Pre-print. Please cite as: Understanding and managing compliance in the nature conservation context. Journal of Environmental Management. doi:

http://dx.doi.org/10.1016/j.jenvman.2015.02.013 


\section{References}

Ainsworth, C. H., Morzaria-Luna, H. N., Kaplan, I. C., Levin, P. S., \& Fulton, E. A. (2012). Full compliance with harvest regulations yields ecological benefits: Northern Gulf of California case study. Journal of Applied Ecology, 49(1), 63-72. doi: 10.1111/j.13652664.2011.02064.x

Ajzen, I. (1992). Persuasive communication Theory in Social Psychology: A Historical Perspective. In M. J. Manfredo (Ed.), Influencing human behavior: theory and application in recreation, tourism, and natural resources management (pp. 1-27). Champaign, Illinois: Sagamore Publishing INC.

Ajzen, I. (2012). Martin Fishbein's Legacy: The Reasoned Action Approach. The ANNALS of the American Academy of Political and Social Science, 640(1), 11-27. doi: $10.1177 / 0002716211423363$

Ajzen, I. (2013). Theory of planned behaviour. Retrieved 16/11/2013, 2013, from http://people.umass.edu/aizen/tpb.html

Ajzen, I., \& Fishbein, M. (2005). The influence of attitudes on behavior. In D. Albarracín, B. T. Johnson \& M. P. Zanna (Eds.), The handbook of attitudes (pp. 173-221). Mahwah, NJ: Erlbaum.

Akella, A. S., \& Cannon, J. B. (2004). Strengthening the weakest links: strategies for improving the enforcement of environmental laws globally: Center for Conservation and Government at Conservation International.

Alder, J. (1996). Costs and effectiveness of education and enforcement, Cairns Section of the Great Barrier Reef Marine Park. Environmental Management, 20(4), 541-551. doi: $10.1007 / \mathrm{bf01474654}$

Arias, A., Pressey, R. L., Jones, R. E., Álvarez-Romero, J., \& Cinner, J. E. (2014). Optimizing enforcement and compliance in offshore marine protected areas: A case study from Coco's Island, Costa Rica. Oryx. doi: http://dx.doi.org/10.1017/S0030605314000337

Arias, A., \& Sutton, S. G. (2013). Understanding recreational fishers' compliance with notake zones in the Great Barrier Reef Marine Park. Ecology and Society, 18(4). doi: http://dx.doi.org/10.5751/ES-05872-180418

Baker, J., Bitariho, R., Gordon-Maclean, A., Kasoma, P., Roe, D., Sheil, D., et al. (2013). Linking protected area conservation with poverty alleviation in Uganda: integrated conservation and development at Bwindi Impenetrable National Park. In J. B. Smith (Ed.), National Parks: Sustainable Development, Conservation Strategies and Environmental Impacts (pp. 47-103): Nova Science Publishers, Inc.

Balmford, A., \& Cowling, R. M. (2006). Fusion or Failure? The Future of Conservation Biology. Conservation Biology, 20(3), 692-695. doi: 10.1111/j.15231739.2006.00434.x

Pre-print. Please cite as: Understanding and managing compliance in the nature conservation context. Journal of Environmental Management. doi:

http://dx.doi.org/10.1016/j.jenvman.2015.02.013 
Ban, N. C., Mills, M., Tam, J., Hicks, C. C., Klain, S., Stoeckl, N., et al. (2013). A socialecological approach to conservation planning: embedding social considerations. Frontiers in Ecology and the Environment, 11(4), 194-202. doi: 10.1890/110205

Barkan, S. E. (2011). Criminology: A sociological understanding (5 ed.). NJ: Prentice Hall

Beck, L., \& Ajzen, I. (1991). Predicting dishonest actions using the theory of planned behavior. Journal of Research in Personality, 25(3), 285-301. doi: http://dx.doi.org/10.1016/0092-6566(91)90021-H

Becker, G. S. (1974). Crime and Punishment: An Economic Approach. In G. S. Becker \& W. M. Landes (Eds.), Essays in the Economics of Crime and Punishment (pp. 1-54): UMI.

Becker, M., McRobb, R., Watson, F., Droge, E., Kanyembo, B., Murdoch, J., et al. (2013). Evaluating wire-snare poaching trends and the impacts of by-catch on elephants and large carnivores. Biological Conservation, 158(0), 26-36. doi: http://dx.doi.org/10.1016/j.biocon.2012.08.017

Bergseth, B. J., Russ, G. R., \& Cinner, J. E. (2013). Measuring and monitoring compliance in no-take marine reserves. Fish and Fisheries, n/a-n/a. doi: 10.1111/faf.12051

Berkes, F., Hughes, T., Steneck, R., Wilson, J. A., Bellwood, D., Crona, B., et al. (2006). Globalization, roving bandits, and marine resources. Science, 311(5767), 1557-1558.

Braithwaite, V., \& Braithwaite, J. (2001). An Evolving Compliance Model for Tax Enforcement. In N. Shover \& J. P. Wright (Eds.), Crimes of Privilege (pp. 405-419). New York: Oxford University Press.

Branch, T. A., Lobo, A. S., \& Purcell, S. W. (2013). Opportunistic exploitation: an overlooked pathway to extinction. Trends in Ecology \& Evolution, 28(7), 409-413. doi: http://dx.doi.org/10.1016/j.tree.2013.03.003

Brooke, S. D., Lim, T. Y., \& Ardron, J. A. (2010). Surveillance and enforcement of remote maritime areas. Paper 1: surveillance technical options (pp. 39). USA: Marine Conservation Biology Institute.

Brown, T. J., Ham, S. H., \& Hughes, M. (2010). Picking up litter: an application of theorybased communication to influence tourist behaviour in protected areas. Journal of Sustainable Tourism, 18(7), 879-900. doi: 10.1080/09669581003721281

Cialdini, R. B. (2003). Crafting Normative Messages to Protect the Environment. Current Directions in Psychological Science, 12(4), 105-109. doi: 10.1111/1467-8721.01242

Cialdini, R. B., \& Goldstein, N. J. (2004). Social influence: Compliance and conformity. Annual Review of Psychology, 55, 591-621.

Cialdini, R. B., Kallgren, C. A., \& Reno, R. R. (1991). A Focus Theory of Normative Conduct: A Theoretical Refinement and Reevaluation of the Role of Norms in Human

Pre-print. Please cite as: Understanding and managing compliance in the nature conservation context. Journal of Environmental Management. doi:

http://dx.doi.org/10.1016/j.jenvman.2015.02.013 
Behavior. In P. Z. Mark (Ed.), Advances in experimental social psychology (Vol. Volume 24, pp. 201-234): Academic Press.

Cialdini, R. B., Reno, R. R., \& Kallgren, C. A. (1990). A focus theory of normative conduct: Recycling the concept of norms to reduce littering in public places. Journal of Personality and Social Psychology, 58(6), 1015.

Cinner, J. E. (2010). Poverty and the use of destructive fishing gear near east African marine protected areas. Environmental Conservation, 36(04), 321-326. doi: doi:10.1017/S0376892910000123

Cinner, J. E., Basurto, X., Fidelman, P., Kuange, J., Lahari, R., \& Mukminin, A. (2012a). Institutional designs of customary fisheries management arrangements in Indonesia, Papua New Guinea, and Mexico. Marine Policy, 36(1), 278-285.

Cinner, J. E., McClanahan, T. R., MacNeil, M. A., Graham, N. A. J., Daw, T. M., Mukminin, A., et al. (2012b). Comanagement of coral reef social-ecological systems. Proceedings of the National Academy of Sciences, USA, 109(14), 5219-5222.

Clayton, L., Keeling, M., \& Milner-Gulland, E. J. (1997). Bringing home the bacon: a spatial model of wild pig hunting in Sulawesi, Indonesia Ecological Applications, 7(2), 642652. doi: 10.1890/1051-0761(1997)007[0642:BHTBAS]2.0.CO;2

Colding, J., \& Folke, C. (2001). Social taboos: “Invisible” systems of local resource management and biological conservation. Ecological Applications, 11(2), 584-600. doi: 10.1890/1051-0761(2001)011[0584:STISOL]2.0.CO;2

Cullen, F. T., \& Agnew, R. (Eds.). (2006). Criminological theory: past to present (essential readings) (3 ed.). Los Angeles, CA: Roxbury Publishing Company.

Davis, K. L. F., Russ, G. R., Williamson, D. H., \& Evans, R. D. (2004). Surveillance and Poaching on Inshore Reefs of the Great Barrier Reef Marine Park. Coastal Management, 32(4), 373-387.

Deci, E. L., Koestner, R., \& Ryan, R. M. (1999). A meta-analytic review of experiments examining the effects of extrinsic rewards on intrinsic motivation. Psychological Bulletin, 125(6), 627.

Dell'Apa, A., Chad Smith, M., \& Kaneshiro-Pineiro, M. (2014). The Influence of Culture on the International Management of Shark Finning. Environmental Management, 1-11. doi: 10.1007/s00267-014-0291-1

Dudley, N., Stolton, S., \& Elliott, W. (2013). Wildlife crime poses unique challenges to protetced areas. Parks, 19.1, 7-12.

Eliason, S. L., \& Dodder, R. A. (1999). Techniques of neutralization used by deer poachers in the western united states: a research note. Deviant Behavior, 20(3), 233-252. doi: $10.1080 / 016396299266489$

Pre-print. Please cite as: Understanding and managing compliance in the nature conservation context. Journal of Environmental Management. doi: http://dx.doi.org/10.1016/j.jenvman.2015.02.013 
Fabinyi, M. (2007). Illegal Fishing and Masculinity in the Philippines: A Look at the Calamianes Islands in Palawan. Philippine Studies, 55(4), 509-529.

Fehr, E., \& Falk, A. (2002). Psychological foundations of incentives. European Economic Review, 46(4), 687-724.

Fehr, E., \& Fischbacher, U. (2003). The nature of human altruism. Nature, 425(6960), 785791.

Ferraro, P. J., \& Hanauer, M. M. (2014). Quantifying causal mechanisms to determine how protected areas affect poverty through changes in ecosystem services and infrastructure. Proceedings of the National Academy of Sciences. doi: 10.1073/pnas.1307712111

Ferraro, P. J., \& Simpson, R. D. (2002). The Cost-Effectiveness of Conservation Payments. Land Economics, 78(3), 339-353. doi: 10.2307/3146894

Fishbein, M., \& Ajzen, I. (2010). Predicting and changing behavior: The reasoned action approach (1 ed.). New York: Taylor \& Francis.

Fishbein, M., \& Manfredo, M. J. (1992). A theory of behavior change. In M. J. Manfredo (Ed.), Influencing human behavior: theory and application in recreation, tourism, and natural resources management (pp. 29-50). Champaign, Illinois: Sagamore Publishing INC.

Frey, B. S. (1999). Morality and rationality in environmental policy. Journal of Consumer Policy, 22(4), 395-417.

Frey, B. S., \& Jegen, R. (2001). Motivation Crowding Theory. Journal of Economic Surveys, 15(5), 589-611. doi: 10.1111/1467-6419.00150

Gavin, M. C., Solomon, J. N., \& Blank, S. G. (2010). Measuring and monitoring illegal use of natural resources. Conservation Biology, 24(1), 89-100.

GBRMPA. (2014). Eyes and ears incident reporting. Retrieved 27/06/2014, 2014, from http://www.gbrmpa.gov.au/our-partners/tourism-industry/eyes-and-earsreporting

Gelcich, S., Edwards-Jones, G., Kaiser, M., \& Castilla, J. (2006). Co-management Policy Can Reduce Resilience in Traditionally Managed Marine Ecosystems. Ecosystems, 9(6), 951-966. doi: 10.1007/s10021-005-0007-8

Gibbs, C., Gore, M. L., McGarrell, E. F., \& Rivers, L. (2010). Introducing Conservation Criminology: Towards Interdisciplinary Scholarship on Environmental Crimes and Risks. British Journal of Criminology, 50(1), 124-144. doi: 10.1093/bjc/azp045

Gibson, C. C. (1999). Politicians and poachers: The political economy of wildlife policy in Africa. Cambridge, United Kingdom: Cambridge University Press.

Gneezy, U., \& Rustichini, A. (2000). A Fine Is a Price. The Journal of Legal Studies, 29(1), 1-17. doi: $10.1086 / 468061$

Pre-print. Please cite as: Understanding and managing compliance in the nature conservation context. Journal of Environmental Management. doi:

http://dx.doi.org/10.1016/j.jenvman.2015.02.013 
Haken, J. (2011). Transnational crime in the developing world. Washington, DC: Global Financial Integrity.

Ham, S. H. (2013). Interpretation-making a difference on purpose. Golden, Colorado: Fulcrum Publishing.

Ham, S. H., Brown, T. J., Curtis, J., Weiler, B., Hughes, M., \& Poll, M. (2009). Promoting persuasion in protected areas: A guide for managers who want to use strategic communication to influence visitor behaviour (1 ed.). Gold Coast, Queensland: Cooperative Research Centre for Sustainable Tourism.

Ham, S. H., Weiler, B., Hughes, M., Brown, T. J., Curtis, J., \& Poll, M. (2008). Asking visitors to help: Research to Guide Strategic Communication for Protected Area Management (pp. 80). Gold Coast, Queensland: Cooperative Research Centre for Sustainable Tourism.

Harland, P., Staats, H., \& Wilke, H. A. M. (1999). Explaining Proenvironmental Intention and Behavior by Personal Norms and the Theory of Planned Behavior1. Journal of Applied Social Psychology, 29(12), 2505-2528. doi: 10.1111/j.15591816.1999.tb00123.x

Harland, P., Staats, H., \& Wilke, H. A. M. (2007). Situational and Personality Factors as Direct or Personal Norm Mediated Predictors of Pro-environmental Behavior: Questions Derived From Norm-activation Theory. Basic and Applied Social Psychology, 29(4), 323-334. doi: 10.1080/01973530701665058

Hart, H. L. A. (1994). The concept of law (Second ed.). New York: Oxford University Press.

Hauck, M., \& Kroese, M. (2006). Fisheries compliance in South Africa: A decade of challenges and reform 1994-2004. Marine Policy, 30(1), 74-83. doi: http://dx.doi.org/10.1016/j.marpol.2005.06.007

Hilborn, R., Arcese, P., Borner, M., Hando, J., Hopcraft, G., Loibooki, M., et al. (2006). Effective enforcement in a conservation area. Science, 314(5803), 1266-1266.

Holmern, T., Muya, J., \& Røskaft, E. (2007). Local law enforcement and illegal bushmeat hunting outside the Serengeti National Park, Tanzania. Environmental Conservation, 34(01), 55-63. doi: doi:10.1017/S0376892907003712

Hønneland, G. (2000). Compliance in the Barents Sea fisheries. How fishermen account for conformity with rules. Marine Policy, 24(1), 11-19. doi: http://dx.doi.org/10.1016/S0308-597X(98)00058-X

Hornik, J., Cherian, J., Madansky, M., \& Narayana, C. (1995). Determinants of recycling behavior: A synthesis of research results. The Journal of Socio-Economics, 24(1), 105-127. doi: http://dx.doi.org/10.1016/1053-5357(95)90032-2

Jaccard, J., \& Blanton, H. (2005). The origins and structure of behaviour: Conceptualizing behaviour in attitude research. In D. Albarracín, B. T. Johnson \& M. P. Zanna (Eds.),

Pre-print. Please cite as: Understanding and managing compliance in the nature conservation context. Journal of Environmental Management. doi:

http://dx.doi.org/10.1016/j.jenvman.2015.02.013 
The handbook of attitudes (pp. 125-171). Mahwah, New Jersey: Lawrence Erlbaum Associates.

Jachmann, H. (2008). Monitoring law-enforcement performance in nine protected areas in Ghana. Biological Conservation, 141(1), 89-99. doi: 10.1016/j.biocon.2007.09.012

Jachmann, H., \& Billiouw, M. (1997). Elephant Poaching and Law Enforcement in the Central Luangwa Valley, Zambia. Journal of Applied Ecology, 34(1), 233-244. doi: $10.2307 / 2404861$

Januchowski-Hartley, F. A., Graham, N. A. J., Cinner, J. E., \& Russ, G. R. (2012). Spillover of fish naïveté from marine reserves. Ecology Letters, 16(2), 191-197. doi: 10.1111/ele.12028

Jones, J. P. G., Andriamarovololona, M. M., \& Hockley, N. (2008). The Importance of Taboos and Social Norms to Conservation in Madagascar. Conservation Biology, 22(4), 976-986. doi: 10.1111/j.1523-1739.2008.00970.x

Kaiser, F. G., Hübner, G., \& Bogner, F. X. (2005). Contrasting the Theory of Planned Behavior With the Value-Belief-Norm Model in Explaining Conservation Behavior1. Journal of Applied Social Psychology, 35(10), 2150-2170. doi: 10.1111/j.15591816.2005.tb02213.x

Kalron, N. (2013). Neo-conservation. African Security Review, 22(3), 160-166. doi: $10.1080 / 10246029.2013 .823795$

Keane, A., Jones, G. P., \& Milner-Gulland, E. J. (2012). Modelling the effect of individual strategic behaviour on community-level outcomes of conservation interventions. Environmental Conservation, 39(04), 305-315. doi: doi:10.1017/S0376892912000124

Keane, A., Jones, J. P. G., Edwards-Jones, G., \& Milner-Gulland, E. J. (2008). The sleeping policeman: understanding issues of enforcement and compliance in conservation. Animal Conservation, 11(2), 75-82.

Klöckner, C. A. (2013). A comprehensive model of the psychology of environmental behaviour-A meta-analysis. Global Environmental Change, 23(5), 1028-1038. doi: http://dx.doi.org/10.1016/j.gloenvcha.2013.05.014

Knapp, E. J., Rentsch, D., Schmitt, J., Lewis, C., \& Polasky, S. (2010). A tale of three villages: choosing an effective method for assessing poaching levels in western Serengeti, Tanzania. Oryx, 44(02), 178-184.

Knopf, R. C., \& Dustin, D. L. (1992). A Multidisciplinary Model for Managing Vandalism and Depreciative Behavior in Recreation Setting. In M. J. Manfredo (Ed.), Influencing human behavior: theory and application in recreation, tourism, and natural resources management (pp. 209-261). Champaign, Illinois: Sagamore Publishing INC.

Kuemmerle, T., Chaskovskyy, O., Knorn, J., Radeloff, V. C., Kruhlov, I., Keeton, W. S., et al. (2009). Forest cover change and illegal logging in the Ukrainian Carpathians in the

Pre-print. Please cite as: Understanding and managing compliance in the nature conservation context. Journal of Environmental Management. doi:

http://dx.doi.org/10.1016/j.jenvman.2015.02.013 
transition period from 1988 to 2007. Remote Sensing of Environment, 113(6), 11941207. doi: http://dx.doi.org/10.1016/j.rse.2009.02.006

Laurance, W. F. (1998). A crisis in the making: responses of Amazonian forests to land use and climate change. Trends in Ecology \& Evolution, 13(10), 411-415. doi: http://dx.doi.org/10.1016/S0169-5347(98)01433-5

Leader-Williams, N., Albon, S. D., \& Berry, P. S. M. (1990). Illegal exploitation of black rhinoceros and elephant populations: patterns of decline, law enforcement and patrol effort in Luangwa Valley, Zambia. Journal of Applied Ecology, 1055-1087.

Lein, J. K. (2009). Implementing remote sensing strategies to support environmental compliance assessment: A neural network application. Environmental Science \& Policy, 12(7), 948-958. doi: http://dx.doi.org/10.1016/j.envsci.2009.08.001

Leisher, C., Mangubhai, S., Hess, S., Widodo, H., Soekirman, T., Tjoe, S., et al. (2012). Measuring the benefits and costs of community education and outreach in marine protected areas. Marine Policy, 36(5), 1005-1011. doi: http://dx.doi.org/10.1016/j.marpol.2012.02.022

Levi, M. (1989). Of rule and revenue. Berkley and Los Angeles, Califonia: University of California Press.

Levi, M., Sacks, A., \& Tyler, T. (2009). Conceptualizing Legitimacy, Measuring Legitimating Beliefs. American Behavioral Scientist, 53(3), 354-375. doi: $10.1177 / 0002764209338797$

Levi, M., Tyler, T. R., \& Sacks, A. (2012). The reasons for compliance with the law. In R. Goodman, D. Jinks \& A. K. Woods (Eds.), Understanding Social Action, Promoting Human Rights (pp. 70-93). New York: Oxford University Press.

Little, L. R., Smith, A. D. M., McDonald, A. D., Punt, A. E., Mapstone, B. D., Pantus, F., et al. (2005). Effects of size and fragmentation of marine reserves and fisher infringement on the catch and biomass of coral trout, Plectropomus leopardus, on the Great Barrier Reef, Australia. Fisheries Management and Ecology, 12(3), 177-188. doi: 10.1111/j.1365-2400.2005.00440.x

Mak, K. K. W., Yanase, H., \& Renneberg, R. (2005). Cyanide fishing and cyanide detection in coral reef fish using chemical tests and biosensors. Biosensors and Bioelectronics, 20(12), 2581-2593. doi: http://dx.doi.org/10.1016/j.bios.2004.09.015

Margoluis, R. A., \& Salafsky, N. (1998). Measures of success. Washington, D.C.: Island Press.

Maslow, A. H. (1943). A theory of human motivation. Psychological Review, 50(4), 370-396. doi: $10.1037 / \mathrm{h} 0054346$

Matthies, E., Klöckner, C. A., \& Preißner, C. L. (2006). Applying a Modified Moral Decision Making Model to Change Habitual Car Use: How Can Commitment be Effective? Applied Psychology, 55(1), 91-106. doi: 10.1111/j.1464-0597.2006.00237.x

Pre-print. Please cite as: Understanding and managing compliance in the nature conservation context. Journal of Environmental Management. doi:

http://dx.doi.org/10.1016/j.jenvman.2015.02.013 
McClanahan, T. R., Marnane, M. J., Cinner, J. E., \& Kiene, W. E. (2006). A comparison of marine protected areas and alternative approaches to coral-reef management. Current Biology, 16(14), 1408-1413.

McCook, L. J., Ayling, T., Cappo, M., Choat, J. H., Evans, R. D., De Freitas, D. M., et al. (2010). Adaptive management of the Great Barrier Reef: A globally significant demonstration of the benefits of networks of marine reserves. Proceedings of the National Academy of Sciences, USA, 107(43), 18278-18285.

McKenzie-Mohr, D. (2000). New Ways to Promote Proenvironmental Behavior: Promoting Sustainable Behavior: An Introduction to Community-Based Social Marketing. Journal of Social Issues, 56(3), 543-554. doi: 10.1111/0022-4537.00183

Milner-Gulland, E. J., \& Leader-Williams, N. (1992). A model of incentives for the illegal exploitation of black rhinos and elephants: poaching pays in Luangwa Valley, Zambia. Journal of Applied Ecology, 388-401.

Milner-Gulland, E. J., \& Rowcliffe, J. M. (2007). Conservation and sustainable use: a handbook of techniques. OUP Catalogue.

MRAG. (2005). Review of Impacts of Illegal, Unreported and Unregulated Fishing on Developing Countries (pp. 178). London, United Kingdom: MRAG.

Nuno, A., Bunnefeld, N., Naiman, L. C., \& Milner-Gulland, E. J. (2013). A Novel Approach to Assessing the Prevalence and Drivers of Illegal Bushmeat Hunting in the Serengeti. Conservation Biology, 27(6), 1355-1365. doi: 10.1111/cobi.12124

Ogden, R. (2008). Fisheries forensics: the use of DNA tools for improving compliance, traceability and enforcement in the fishing industry. Fish and Fisheries, 9(4), 462472. doi: 10.1111/j.1467-2979.2008.00305.x

Ogden, R., Dawnay, N., \& McEwing, R. (2009). Wildlife DNA forensics_-bridging the gap between conservation genetics and law enforcement. Endangered Species Research, 9(3), 179-195.

Ostrom, E. (1990). Governing the commons: The evolution of institutions for collective action. Cambridge, UK: Cambridge University Press.

Ostrom, E. (2000). Collective Action and the Evolution of Social Norms. The Journal of Economic Perspectives, 14(3), 137-158. doi: 10.2307/2646923

Peluso, N. L. (1993). Coercing conservation?: The politics of state resource control. Global Environmental Change, 3(2), 199-217. doi: 10.1016/0959-3780(93)90006-7

Pressey, R. L., \& Bottrill, M. C. (2009). Approaches to landscape-and seascape-scale conservation planning: convergence, contrasts and challenges. Oryx, 43(4), 464-475.

Robinson, E. J. Z., Kumar, A. M., \& Albers, H. J. (2010). Protecting Developing Countries' Forests: Enforcement in Theory and Practice. Journal of Natural Resources Policy Research, 2(1), 25-38. doi: 10.1080/19390450903350820

Pre-print. Please cite as: Understanding and managing compliance in the nature conservation context. Journal of Environmental Management. doi:

http://dx.doi.org/10.1016/j.jenvman.2015.02.013 
Rogers, R. W. (1975). A Protection Motivation Theory of Fear Appeals and Attitude Change. The Journal of Psychology, 91(1), 93-114. doi: 10.1080/00223980.1975.9915803

Roggenbuck, J. W. (1992). Use of persuasion to reduce resource impacts and visitor conflicts. In M. J. Manfredo (Ed.), Influencing human behavior: theory and application in recreation, tourism, and natural resources management (pp. 149-208). Champaign, Illinois: Sagamore Publishing INC.

Sadovy de Mitcheson, Y., Cornish, A., Domeier, M., Colin, P. L., Russell, M., \& Lindeman, K. C. (2008). A Global Baseline for Spawning Aggregations of Reef Fishes. Conservation Biology, 22(5), 1233-1244. doi: 10.1111/j.1523-1739.2008.01020.x

Sala, E., Ballesteros, E., \& Starr, R. M. (2001). Rapid Decline of Nassau Grouper Spawning Aggregations in Belize: Fishery Management and Conservation Needs. Fisheries, 26(10), 23-30. doi: 10.1577/1548-8446(2001)026<0023:RDONGS>2.0.CO;2

Schill, D., \& Kline, P. A. (1995). Use of random response to estimate angler noncompliance with fishing regulations. North American Journal of Fisheries Management, 15(4), 721-731.

Schultz, P. W. (2002). Knowledge, information, and household recycling: Examining the knowledge-deficit model of behavior change. In T. Dietz \& P. Stern (Eds.), New tools for environmental protection: Education, information, and voluntary measures (pp. 67-82). Washington, DC: National Academy of Sciences.

Schultz, P. W. (2011). Conservation means behavior. Conservation Biology, 25(6), 10801083.

Schultz, P. W., Nolan, J. M., Cialdini, R. B., Goldstein, N. J., \& Griskevicius, V. (2007). The Constructive, Destructive, and Reconstructive Power of Social Norms. Psychological Science, 18(5), 429-434. doi: 10.1111/j.1467-9280.2007.01917.x

Schwartz, S. H. (1973). Normative explanations of helping behavior: A critique, proposal, and empirical test. Journal of Experimental Social Psychology, 9(4), 349-364. doi: http://dx.doi.org/10.1016/0022-1031(73)90071-1

Schwartz, S. H. (1977). Normative influences on altruism. Advances in experimental social psychology, 10, 221-279.

Sievanen, L., Crawford, B., Pollnac, R., \& Lowe, C. (2005). Weeding through assumptions of livelihood approaches in ICM: Seaweed farming in the Philippines and Indonesia. Ocean \& Coastal Management, 48(3-6), 297-313. doi: http://dx.doi.org/10.1016/j.ocecoaman.2005.04.015

St. John, F. A. V., Edwards-Jones, G., \& Jones, J. P. G. (2010). Conservation and human behaviour: lessons from social psychology. Wildlife Research, 37(8), 658-667. doi: http://dx.doi.org/10.1071/WR10032

St. John, F. A. V., Keane, A. M., \& Milner-Gulland, E. J. (2013). Effective conservation depends upon understanding human behaviour. In D. W. MacDonald \& K. J. Willis

Pre-print. Please cite as: Understanding and managing compliance in the nature conservation context. Journal of Environmental Management. doi:

http://dx.doi.org/10.1016/j.jenvman.2015.02.013 
(Eds.), Key Topics in Conservation Biology 2 (pp. 344-361). West Sussex, UK: John Wiley \& Sons.

Stern, M. J. (2008). Coercion, voluntary compliance and protest: the role of trust and legitimacy in combating local opposition to protected areas. Environmental Conservation, 35(3), 200-210.

Stiles, D. (2004). The ivory trade and elephant conservation. Environmental Conservation, 31(04), 309-321. doi: doi:10.1017/S0376892904001614

Stonehouse, D. P. (1996). A targeted policy approach to inducing improved rates of conservation compliance in agriculture. Canadian Journal of Agricultural Economics/Revue canadienne d'agroeconomie, 44(2), 105-119.

Sumner, W. G. (1906). Folkways: A study of the sociological importance of usage, manners, customs, mores, and morals. Boston: Ginn.

Sundström, A. (2012). Corruption and regulatory compliance: Experimental findings from South African small-scale fisheries. Marine Policy, 36(6), 1255-1264. doi: http://dx.doi.org/10.1016/j.marpol.2012.03.013

Sutinen, J. G. (1987). Enforcement of the MFCMA: an economist's perspective. Marine Fisheries Review, 49(3), 36-43.

Sutinen, J. G., \& Andersen, P. (1985). The Economics of Fisheries Law Enforcement. Land Economics, 61(4), 387-397.

Sutinen, J. G., \& Kuperan, K. (1999). A socio-economic theory of regulatory compliance. International journal of social economics, 26(1/2/3), 174-193.

Tyler, T. R. (1990). Why people obey the law. New Haven: Yale University Press.

Tyler, T. R. (2003). Procedural Justice, Legitimacy, and the Effective Rule of Law. Crime and Justice, 30, 283-357.

Wilkie, D. S., Bennett, E. L., Peres, C. A., \& Cunningham, A. A. (2011). The empty forest revisited. Annals of the New York Academy of Sciences, 1223(1), 120-128.

Winfree, L. T., \& Abadinsky, H. (2009). Understanding crime: Essentials of criminological theory (3 ed.). California: Wadsworth.

Wunder, S. (2000). Ecotourism and economic incentives — an empirical approach. Ecological Economics, 32(3), 465-479. doi: http://dx.doi.org/10.1016/S0921$\underline{\text { 8009(99)00119-6 }}$

Pre-print. Please cite as: Understanding and managing compliance in the nature conservation context. Journal of Environmental Management. doi:

http://dx.doi.org/10.1016/j.jenvman.2015.02.013 